\title{
外傷性嵌入歯牙に起因したと思われる上顎洞炎の1例
}

\author{
九州雨科大学第 2 口腔外科学教室（指導：池尻 茂教授） \\ 今里 洋…‥原田 利夫・古本 克磨
}

A Case of Sinusitis Due to the Tooth Inlayed through External Injuries

Yohichi Imazato, Toshio Harada and Katsuma Komoto

Second Department of Oral Surgery (Director: Prof. Shigeru Ikejiri)

Kyushu Dental College, Kitakyushu, Japan

（本論文の要旨は第25回日本口腔外科学会九州地方部会において口演した。）

The patient, a man aged 47, sustained the injury of his upper jaw and lost the $\underline{5-1}$ teeth in a traffic accident three years ago. A year after the accident, the maxillary sinusitis occurred and persisted despite the conservative treatment by an otorhinolaryngologist for two years. Recently, the patient was reffered to our department with a suspicion of a foreign body lying adjacent to the affected antrum.X-ray revealed the presence of tooth-like opaque adjoining the internal wall of the left antrum, so we operated to remove it under the local anesthesia on 20th May, 1974. The tooth-like body was found to be the left upper incisor that was inferred to have been inlayed in the accident. The tooth projected into the antrum, but the radical sinuotomy was not carried out for absence of remarkable inflammation on the antrum membrane. The post medication was indicated for a week, and any sign of sinusitis clearly disappeared.

This case points out that a thorough examination at first could have prevented the patient from unnecessary sufferings and that one should never take things for granted in treatment, even of an apparent routine case.

\section{A はじめに}

外傷性異物に起因する上䫑洞炎は日常臨床上，また文 献報告においても少なくない，最近，外傷時の嵌入歯牙 に起因したと思われる上顎洞炎の 1 例に遭遇し，罰顔面 損傷に対する彰察上，示唆される点を得たので報告す る.

\section{B 症例}

患者は 42 才，男性. 当科受診（昭和 49 年 4 月 24 日）の

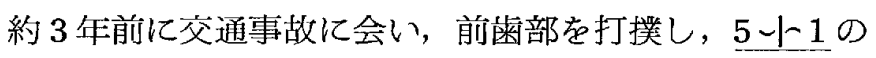
脱臼培失を来たし，直ちに，外科医による創傷処置を受 けた. 受傷 1 年後に, 左側鼻汁 ・鼻閉々眼窩下部の腫 脤, 発赤, 疼痛を認めたため耳鼻科を受診し, 左側上顎 洞炎の診断を受けた。. その後 2 年間, 種々の保存療法を 続け，症状のわずかな緩解を得るも完治するに至らなわ った. 昭和 49 年 4 月, 同耳鼻科医上り，左側上顎洞付近 の異物の存在を指摘され，当科を受診した。

当科受診時の所見として, 左側眼窩下部の軽度のびま
ん性腫脹と発赤，ならびに圧痛を認めた。開口障害はな く， 5ート1 の菌牙欠損を認めた， 1 相当部の酿唇移行部 を触診すると, 凹凹のある骨様硬様硬固物を触れ，その 部の圧痛は著明であるが，当部の粘膜には発赤・腯脹は なく，波動等も触れ得なかった。

鼻閉感を挀える左側鼻腔内には黄白色の膿汁樣鼻汁が あり, 鼻腔粘膜の発赤・腫脹を認め, 特に下鼻道, 中鼻 道, および外側壁粘膜において著明であった。

また，朝，起立時に頭重感と共に悪臭のある鼻汁を認 めると述べた．なお，患者は 3 年前の交通事故以前に副 鼻腔炎，あるいは副鼻腔炎症状を示したことはないと述 ベた.

\section{X線所見}

1 1 根尖相当部に菌冠部を上方に向けて翻転して位置し

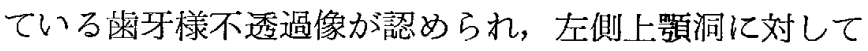
は, 㐘冠隅角部において鼻腔側洞底部と接し, 洞との交

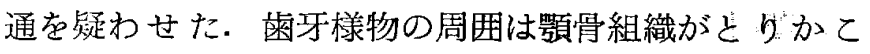




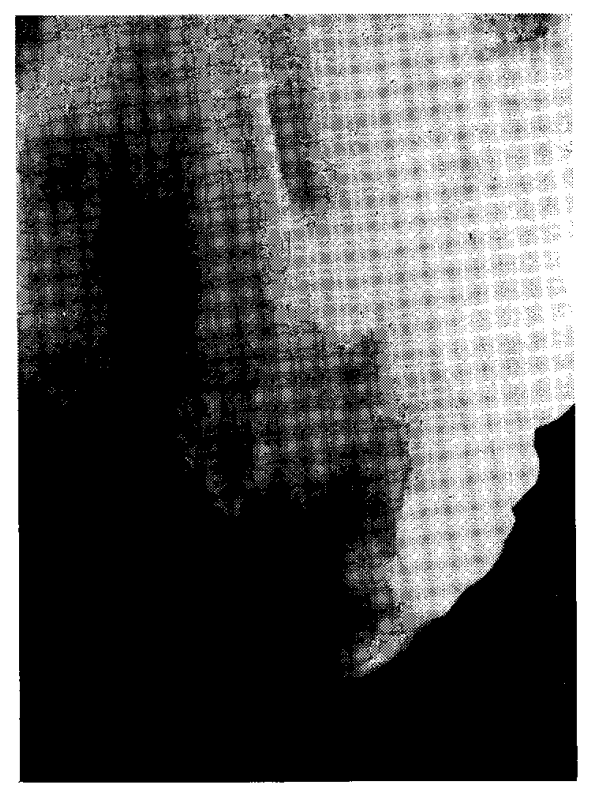

Photo. 1 Occulsal View Shows the tooth-like opaque.

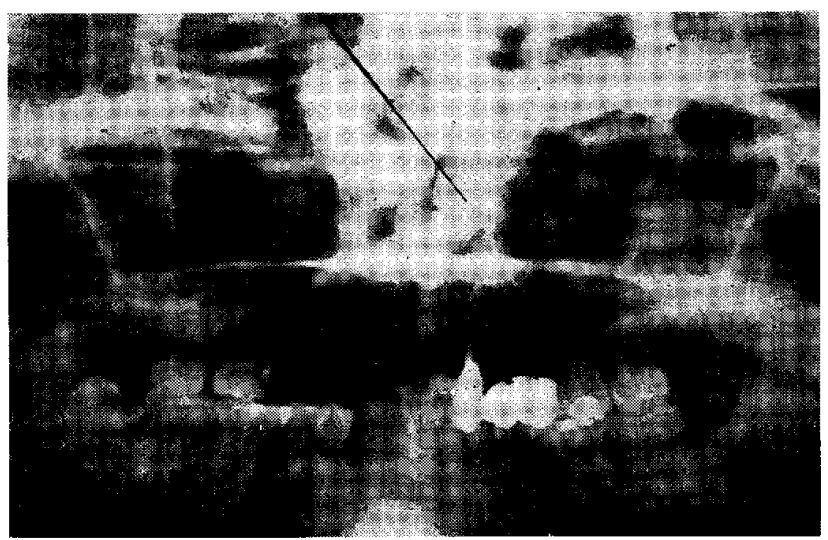

Photo. 2 Orthopantomogram

Shows the tooth-like opaque adjoining the internal wall of left antrum.

み，菌根膜や䨑霊様の像は認められなかった。

左右上颚洞の透過性の違いは明らかではなく，また， これらの所罗は䜿科用フィルムでは不明で, 後前法, な らびに Water 氏法で明らかであった（写真 1-3）。

\section{D 処置ならびに経過}

同年 5 月 20 日，局所麻唒下に盐牙の摘出を試みた。 $2+1$ 相当部の唇側蒾槽粘膜に横切開を加元, 粘膜骨膜

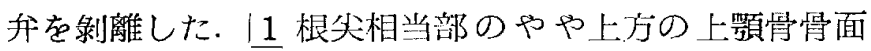
上に瘢痕梯の軟組織に被包された厡牙の根尖部を認めた ・歯牙は舌側面を前方に向け, 翻転した位置で上顎洞の 正中側底部において，商冠部を洞内に乫出させ，上影 洞と交通していた。洞粘膜は交通孔周囲に発赤を諗めた が，著明な炎症所見もなく，膿汁も認められなかったの

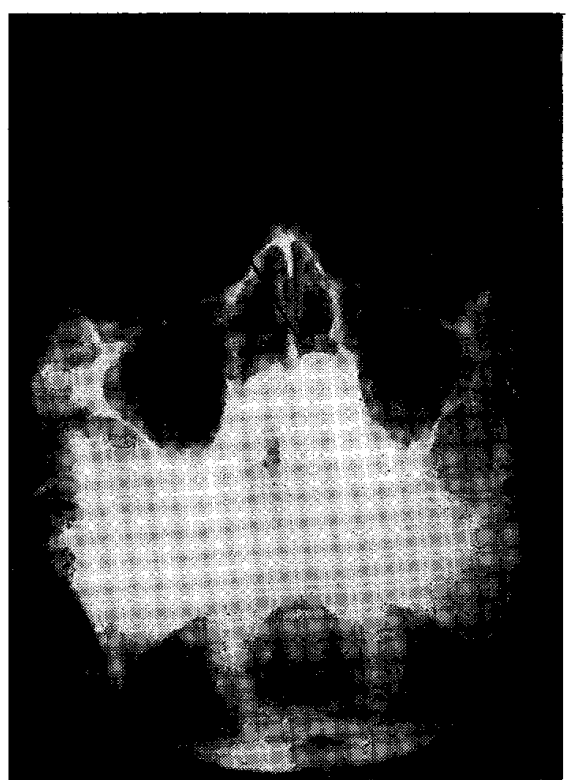

Photo. 3 Water's View

で，根治手術を行なうことなく粈膜婴膜升を䦐鎖して手 術を終了した。

摘出された䔪牙は解剖学的形態より 1 と断定され, 齿 冠近心面にはタバコのヤニと思われる色素の沈着があ

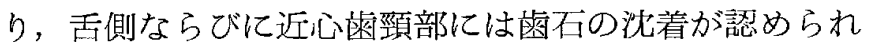
た. 術後, 1 週間の消炎療法を行ない, 諸症状の完全消

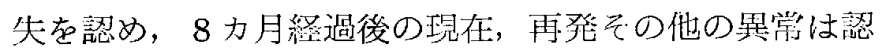
めていない.

\section{E 考 察}

外僨に際しては㢣急迅速な処置を要求されることが多 い. そのため, ややもすれば粗略な彰察に処し易く, 時 に異物等を看過することがある。

創傷部の精査, 入念な問䜌の肝要性については既に幾 多の成䘠にも強調されている. 顎顔面損傷に際しても,

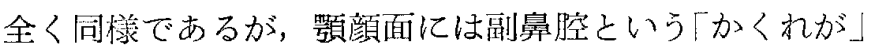
(1969) ${ }^{1}{ }^{\prime}$ があり，さらに一層の注意が喚起される.

本症例は, 2 年間の保存療法により, 急性症状を来た

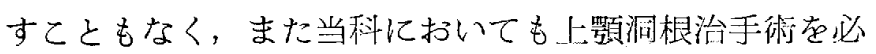
要とはしなかった。しかしながら, 嵌入曾牙汇凉する考 慮が早期からなされていれば， 2 年間という長い経過を 要しなかったと考えられる。

\section{F むすび}

交通外傷時に画牙が嵌入し， 1 年後に登症した上顎洞 炎の症例で， 3 年後の嵌入亚牙摘出によって完治した 1 例を報告した。

\section{文献}

1) 高橋良 - 他：鼻副鼻腔外傷, 耳鼻咽喉科 $41: 771$ $-778,1969$. 